\title{
Post-Anthesis Photosynthetic Properties Provide Insights into Yield Potential of Tartary Buckwheat Cultivars
}

\author{
Dabing Xiang ${ }^{1}{ }^{1}$, Chengrui Ma $^{1}$, Yue Song ${ }^{1}, \mathrm{Qi} \mathrm{Wu}{ }^{1}$, Xiaoyong $\mathrm{Wu}^{1}{ }^{1}$, Yanxia Sun ${ }^{1}$, \\ Gang Zhao ${ }^{2}$ and Yan Wan ${ }^{1, *}$ \\ 1 College of Pharmacy and Biological Engineering, Chengdu University, Chengdu 610106, China; \\ dabing.xiang@163.com (D.X.); mcr1953@outlook.com (C.M.); songsongzp1001@163.com (Y.S.); \\ jerviswuqi@126.com (Q.W.); cduwxysyx@126.com (X.W.); sunyanxia1976@cdu.edu.cn (Y.S.) \\ 2 Key Laboratory of Coarse Cereal Processing, Ministry of Agriculture and Rural Affairs, Chengdu 610106, \\ China; zhaogang@cdu.edu.cn \\ * Correspondence: wanyanyanbest@126.com; Tel.: +86-028-84616790
}

Received: 21 February 2019; Accepted: 18 March 2019; Published: 21 March 2019

\begin{abstract}
Photosynthesis is the basis for plant productivity, and improvement of photosynthetic efficiency is an important way to improve crop yield. However, the relationship between photosynthetic parameters and the yield of Tartary buckwheat (Fagopyrum tataricum) under rainfed conditions is unclear. A two-year field trial was conducted during 2016 and 2017 to assess the photosynthetic capacity of different leaves, dry matter accumulation, and yield of four Tartary buckwheat cultivars from flowering to maturity. The leaves of all cultivars aged gradually after flowering, and the leaf chlorophyll (Chl) and soluble protein (SP) contents, net photosynthetic rates $\left(P_{n}\right)$, transpiration rates $\left(T_{r}\right)$, and stomatal conductance $\left(G_{s}\right)$ tended to decline. The Chl, SP, $P_{n}, T_{r}$, and $\mathrm{G}_{\mathrm{s}}$ of cultivars (cvs.) XiQiao2 and QianKu3 were significantly higher than those of LiuKu3 and JiuJiang at each sampling time from 18 days after anthesis to maturity, but the intercellular $\mathrm{CO}_{2}$ content $\left(\mathrm{C}_{\mathrm{i}}\right)$ showed the opposite trend. Cultivars XiQiao2 and QianKu3 produced more total dry matter (mean $17.1 \%$ higher), had higher harvest index (HI, mean $16.4 \%$ higher), and yield (mean 29.0\% higher) than cvs. LiuKu3 and JiuJiang at maturity, and the difference was remarkably consistent. The yield of all the cultivars was positively correlated with leaf Chl, SP, $P_{n}, T_{r}$, and $G_{s}$, but negatively correlated with $C_{i}$. At late growth stages, the high-yielding cultivars maintained higher Chl, SP contents, $P_{n}, T_{r}$, and $G_{s}$, and showed higher dry matter accumulation and lower $C_{i}$ than the low-yielding cultivars, consistent with their higher leaf photosynthetic capacity. The important factors determining the yield of Tartary buckwheat were maintaining higher leaf Chl and SP content and photosynthetic capacity and delaying aging during the grain formation stage. Enhanced rates of photosynthesis and dry matter accumulation led to higher post-anthesis accumulation of biomass with a positive impact on grain number and higher yield.
\end{abstract}

Keywords: Fagopyrum tataricum; chlorophyll content; photosynthetic parameters; dry matter; yield

\section{Introduction}

Tartary buckwheat (Fagopyrum tataricum (L.) Gaertn.) is a dicotyledonous plant of the family Polygonaceae. It is widely grown worldwide (such as India, Russia, Japan, France, Canada, Poland, Slovenia, and Nepal) for its medicinal and nutritive value but could be more fully utilized as a resource for human consumption [1-3]. It has been called one of the most complete and nutritious foods, being rich in minerals, vitamins, protein, dietary fiber, amino acids, trace elements, and various bioactive phytochemicals [4-8]. Due to its potential health benefits, Tartary buckwheat is consumed 
by an increasing number of people globally [9]. Thus, interest in its consumption to benefit health is growing. At the same time, farmers are eager to increase the yields of the crop to meet the increasing market demand and improve their overall returns. However, the yield of Tartary buckwheat is very low, typically below $1500 \mathrm{~kg} \mathrm{ha}^{-1}$ worldwide $[2,10]$. The most limiting factor determining yield is unclear and, therefore, there is a lack of agricultural strategies to improve yield, resulting in low and unstable grain yields with current production.

Photosynthesis is the basis for yield formation in crops. Li et al. [11] reported that grain yields are positively associated with photosynthetic capacity. Photosynthesis is the main driving force influencing dry matter partitioning and organ formation, and it is the basis of plant production [12,13]. Previous studies have indicated that higher-yielding crops tended to show higher leaf photosynthetic efficiency, and the photosynthetic parameters [net photosynthetic rates $\left(\mathrm{P}_{\mathrm{n}}\right)$, stomatal conductance $\left(\mathrm{G}_{\mathrm{s}}\right)$, intercellular $\mathrm{CO}_{2}$ concentration $\left(\mathrm{C}_{\mathrm{i}}\right)$ and transpiration rates $\left.\left(\mathrm{T}_{\mathrm{r}}\right)\right]$ reflected crop photosynthetic efficiency and could be used to evaluate the performance of different cultivars [14-17]. Photosynthetic efficiency differs at different crop growth stages, and differences in the proportion that photosynthesis contributes to yield could be found at different growth stages [18,19].

Tartary buckwheat has an indeterminate growth habit that results in a high demand for photosynthates after anthesis to support simultaneous flowering, fruiting and grain filling [20]. After anthesis, carbon assimilation from the photosynthetic organs plays a crucial role in determining yield. Furthermore, photosynthesis reaches a peak after anthesis and over $70 \%$ of wheat yield is derived from photosynthesis during the period of grain growth [20,21]. Many researchers have reported that photosynthesis after anthesis is crucial determinant of yield in other crops, such as rice [22], maize [23], and soybean [24]. The contribution to photosynthesis of different leaves in the same plant can differ, and there is a difference among different crops in the contribution by functional leaves $[25,26]$. The functional leaves play a key role in photosynthesis, dry matter production and yield formation. Ou et al. [27] found that flag leaves of high-yielding rice have high chlorophyll content at the reproductive stage, which is the critical for yield formation [28].

Tartary buckwheat has four main functional leaves during grain filling, and these leaves account for a large proportion of photosynthesis during this period [20]. The photosynthetic capacity of the functional leaves is a key factor determining Tartary buckwheat yield, especially under adverse conditions, such as drought or nutrient deficiency [21,29]. Fayez and Hassanein [30] reported that higher leaf chlorophyll contents and delayed leaf senescence could improve photosynthetic capacity. Wheat varieties with high yield potentials can be obtained by selecting for delayed leaf senescence [31]. Several studies have reported that high-yielding cultivars have beneficial photosynthetic parameters, enabling them to grow better. In such cultivars, greater accumulation of dry matter largely contributes to the increased grain yield $[23,32,33]$.

The results of previous studies have provided useful information on the photosynthetic and physiological mechanisms that contribute to yield in other crops. However, there have been few reports concerned photosynthesis and its relationship with yield in Tartary buckwheat. Therefore, this study was conducted to evaluate the relationship between photosynthetic parameters and yield of Tartary buckwheat. We aim to elucidate whether post-anthesis photosynthesis is the main factor determining yield, and to provide a theoretical basis for studying the photosynthetic physiology of Tartary buckwheat. The results of this study will be useful for developing high-yielding cultivation techniques for this important crop.

\section{Materials and Methods}

\subsection{Experimental Materials}

Four Tartary buckwheat cultivars were obtained from the National Research and Development Center for Coarse Cereal Processing, Chengdu University, Chengdu, China: two high-yielding cultivars (XiQiao2 and QianKu3), and two low-yielding ones (LiuKu3 and JiuJiang). The yields of these cultivars 
were reported by the state regional Tartary buckwheat cultivar trial of China. These cultivars were chosen because they are the most widely planted cultivars in Southwest China, and their yield performance has been reported by numerous researchers [34-38].

\subsection{Site Description}

The experiment was conducted at the Teaching and Experimental Farm of Chengdu University $\left(30^{\circ} 65^{\prime} \mathrm{N}, 104^{\circ} 19^{\prime} \mathrm{E}, 495 \mathrm{~m}\right.$ altitude), Sichuan Province, China. Meteorological data for 2016 and 2017 growing seasons, provided by Chengdu Meteorological Station, are presented in Table 1 . The soil is a clay loam; the top $20 \mathrm{~cm}$ soil layer has $\mathrm{pH} 7.16,24.4 \mathrm{~g} \mathrm{~kg}^{-1}$ organic matter, $1.21 \mathrm{~g} \mathrm{~kg}^{-1}$ total N, $0.51 \mathrm{~g}$ $\mathrm{kg}^{-1}$ total $\mathrm{P}, 8.2 \mathrm{~g} \mathrm{~kg}^{-1}$ total $\mathrm{K}, 114.1 \mathrm{mg} \mathrm{kg}^{-1}$ available $\mathrm{N}, 21.5 \mathrm{mg} \mathrm{kg}^{-1}$ Olsen-P, and $105 \mathrm{mg} \mathrm{kg}^{-1}$ available K. The soil physical properties $(0-0.2 \mathrm{~m})$ were determined according to the method proposed by Peng et al. [39].

Table 1. Temperature, rainfall, and solar radiation at the experimental farm during the growing seasons of 2016 and 2017.

\begin{tabular}{|c|c|c|c|c|c|c|}
\hline Year & Month & $\begin{array}{c}\text { Mean } \\
\text { Temperature } \\
\left({ }^{\circ} \mathrm{C}\right)\end{array}$ & $\begin{array}{c}\text { Maximum } \\
\text { Temperature } \\
\left({ }^{\circ} \mathrm{C}\right)\end{array}$ & $\begin{array}{l}\text { Minimum } \\
\text { Temperature } \\
\left({ }^{\circ} \mathrm{C}\right)\end{array}$ & $\begin{array}{l}\text { Precipitation } \\
(\mathrm{mm})\end{array}$ & $\begin{array}{c}\text { Daily Total } \\
\text { Radiation } \\
\left(\mathrm{MJ} \mathrm{m}^{-2} \mathrm{~d}^{-1}\right)\end{array}$ \\
\hline \multirow{5}{*}{2016} & March & 13.5 & 23.1 & 5.1 & 21.5 & 12.5 \\
\hline & April & 19.1 & 27.3 & 11.6 & 38.7 & 17.9 \\
\hline & May & 21.5 & 30.2 & 12.5 & 33.9 & 23.9 \\
\hline & June & 25.3 & 29.5 & 17.3 & 41.2 & 24.2 \\
\hline & March & 12.6 & 23.4 & 5.2 & 19.5 & 13.1 \\
\hline \multirow{3}{*}{2017} & April & 18.5 & 28.0 & 10.4 & 40.2 & 17.6 \\
\hline & May & 22.5 & 33.1 & 17.2 & 45.6 & 23.1 \\
\hline & June & 24.3 & 31.5 & 17.1 & 39.6 & 25.3 \\
\hline
\end{tabular}

\subsection{Experimental Design and Field Management}

The experiment was arranged as a randomized complete block design with three replications (12 plots). The seeds were sown on 22 March 2016 and 25 March 2017. The plots were $2 \mathrm{~m} \times 6 \mathrm{~m}$ (length $\times$ width) with fifteen rows, and seeds were planted with spacing of $20 \mathrm{~cm}$ within rows and $40 \mathrm{~cm}$ between rows. Healthy Tartary buckwheat seeds were surface-sterilized for $5 \mathrm{~min}$ in $0.1 \%$ $w / v$ potassium permanganate solution followed by four 1-min rinses in deionized water. Then the seeds were soaked in sterilized water at $25^{\circ} \mathrm{C}$ for $4 \mathrm{~h}$. Seedlings were thinned to the final density (100 plants $\mathrm{m}^{-2}$ ) at $15 \mathrm{~d}$ after emergence. Insects, diseases, and weeds were controlled intensively to avoid yield losses, and synthetic fertilizer (15:15:15) was applied before planting as basal fertilizer at the rate of $600 \mathrm{~kg} \mathrm{ha}^{-1}$. Other management was based on optimized standards of field production.

Beginning at anthesis, leaves were sampled between 08:00-09:00 h every $9 \mathrm{~d}$. Leaves were sampled from the stem at the 6th, 7th, 8th, and 9th flowering nodes; these were termed functional leaves [20]. The sampled leaves were placed in a cooler box, brought to the laboratory, cleaned with water and blotted with filter paper. The crop was harvested on 23 June 2016 and 27 June 2017.

\subsection{Chlorophyll Content (Chl)}

Leaves from the same sampling positions described above (Section 2.3) were used to quantify chlorophyll (Chl) content. Leaf samples were powdered in liquid nitrogen then incubated in $80 \%$ acetone for $12 \mathrm{~h}$ in darkness at $-20^{\circ} \mathrm{C}$. Extracts were centrifuged at $12,000 \times \mathrm{g}$ for $5 \mathrm{~min}$ at $4{ }^{\circ} \mathrm{C}$. Chl was quantified by measuring absorbance at 645 and $663 \mathrm{~nm}$ using a UV-3200S spectrophotometer (MAPADA Instruments, Shanghai, China); Chl content was calculated as the sum of $\left(20.2 \times \mathrm{A}_{645}+\right.$ $\left.8.02 \times \mathrm{A}_{663}\right)$ and expressed as $\mathrm{mg} \mathrm{g}^{-1}$ fresh weight. Three replicates were used for each measurement. 


\subsection{Soluble Protein (SP)}

Leaves from the same sampling positions as described above (Section 2.3) were used to determine soluble protein (SP) content. The SP was measured with the Coomassie brilliant blue G-250 staining method described by Xiong [40].

\subsection{Photosynthetic Parameters}

The photosynthetic parameters were measured with a portable GFS-3000 photosynthesis system (WALZ Inc., Effeltrich, Germany). Photosynthetically-active radiation was provided by a red-blue light source set at $1200 \mu \mathrm{mol} \mathrm{m} \mathrm{m}^{-2} \mathrm{~s}^{-1}$. The measurements were always made between 09:30 and 12:00 $\mathrm{h}$. The data for $P_{n}, T_{r}, G_{s}$, and $C_{i}$ were automatically recorded by the machine.

\subsection{Dry Matter, Yield, Yield Components, and Harvest Index}

In this experiment, 30 plants were collected randomly from the central rows of each plot at 9 $\mathrm{d}$ and $45 \mathrm{~d}$ after anthesis (DAA), when at least $70 \%$ grains were mature. These samples were used to measure dry matter, yield and its components (grain number per plant and 1000-grain weight). The whole plant was dried to a constant weight at $65{ }^{\circ} \mathrm{C}$ after exposure to $105^{\circ} \mathrm{C}$ for $0.5 \mathrm{~h}$, and the dry weight was measured. A grain sample per plot was oven-dried at $65^{\circ} \mathrm{C}$ for $48 \mathrm{~h}$ then the 1000 -grain weight was measured. Harvest index (HI) was calculated by dividing the total grain weight by the above-ground dry matter weight at maturity.

\subsection{Statistical Analyses}

Microsoft Excel 2010 (Microsoft Corporation, Santa Rosa, California, USA), Microsoft Publisher 2016 (Microsoft Corporation), and SigmaPlot 10.0 (Systat Software Inc., San Jose, California, USA) were used to process the data and draw figures, and SPSS Statistics 17.0 (IBM, Chicago, IL, USA) was used for analysis of variance. There were consistent change characteristics in physiological parameters $(\mathrm{Chl}$, $\mathrm{SP}, \mathrm{P}_{\mathrm{n}}, \mathrm{C}_{\mathrm{i}}, \mathrm{G}_{\mathrm{s}}, \mathrm{T}_{\mathrm{r}}$ ) between 2016 and 2017. No significant difference was observed across years and there were no significant interaction effects (Year $\times$ Cultivar), so we analyzed data averaged across the two years. The differences among treatments were tested by Tukey's multiple comparison test $(p<0.05)$.

\section{Results}

\subsection{Leaf Chl Content}

As shown in Figure 1, the leaf Chl contents of the different cultivars tended to decline from 18 DAA onwards. Leaf senescence in all cultivars initiated at the lower nodes and gradually progressed to the upper nodes. From 27 DAA, the leaf Chl contents of XiQiao2 and QianKu3 were significantly higher than those of LiuKu3 and JiuJiang. When LiuKu3 and JiuJiang approached maturity, the Chl content was the lowest in the 6th leaf, and other leaves showed an obvious tendency to fade from green.

\subsection{Leaf SP Content}

The leaf SP content of all four cultivars decreased with growth stage (Figure 2). There was no difference among cultivars at 9 or 18 DAA, but from 27 DAA onwards the high-yielding cultivars (XiQiao2 and QianKu3) had significantly higher leaf SP than did the low-yielding cultivars (LiuKu3 and JiuJiang). Considering the different functional leaves of each cultivar, the leaf SP contents were lower in lower nodes than in upper nodes at the same growth stage. The higher SP in the cultivars XiQiao2 and QianKu3 than in LiuKu3 and JiuJiang, suggested the high-yielding cultivars maintained stronger physiological activities than the low-yielding cultivars, and their leaves senesced more slowly. 


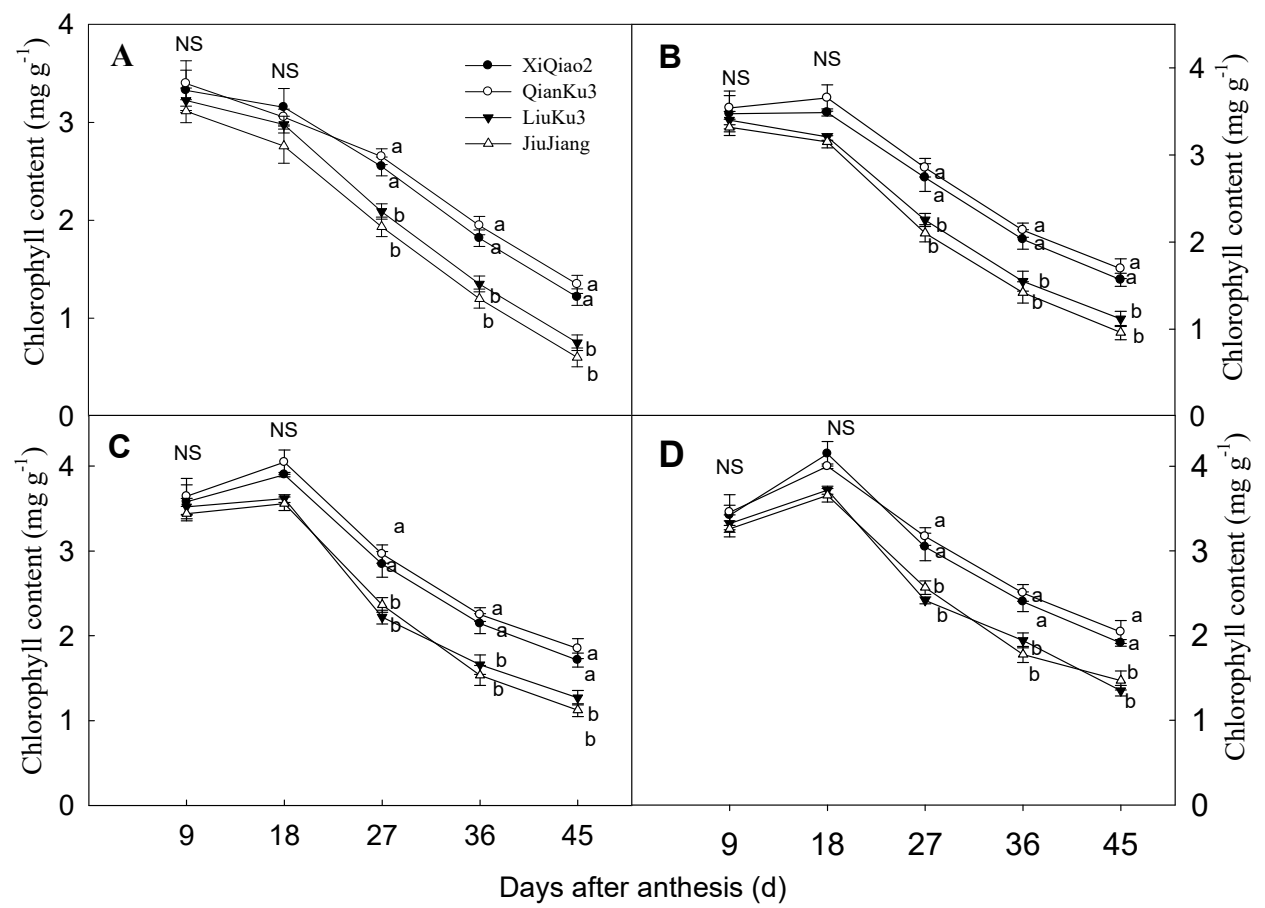

Figure 1. Chlorophyll (Chl) content in the leaves of four Tartary buckwheat cultivars at different flowering nodes. Panels A, B, C, D show results for leaves of the 6th, 7th, 8th, and 9th flowering nodes, respectively. Data are means \pm SD of two years (2016 and 2017). Letters a and b denote significant differences between cultivars $(p<0.05)$ in chlorophyll content at the same day after anthesis. NS: no significant difference.

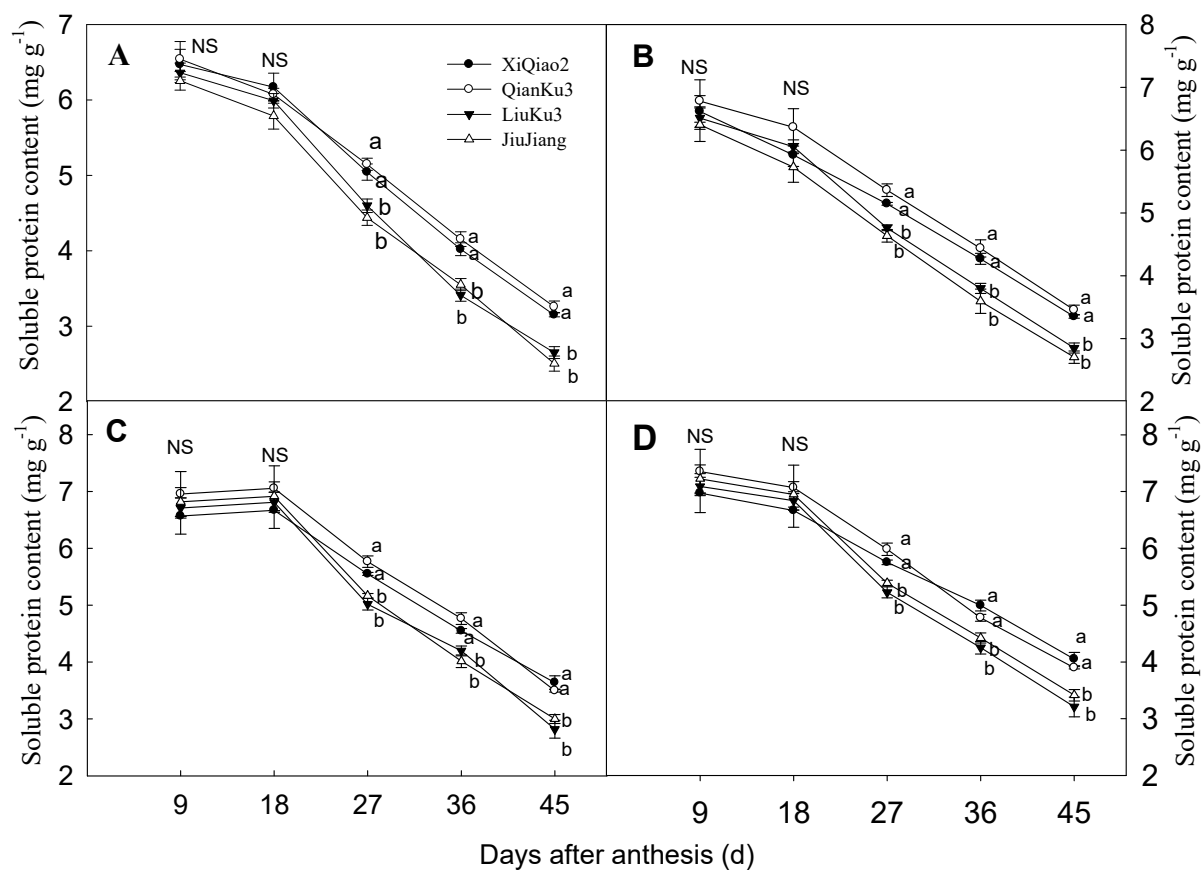

Figure 2. Soluble protein (SP) content in the leaves of four Tartary buckwheat cultivars at different flowering nodes. Panels (A-D) show results for the leaves of the 6th, 7th, 8th, and 9th flowering nodes, respectively. Data are means \pm SD of two years (2016 and 2017). Letters a and b denote significant differences between cultivars $(p<0.05)$ at the same day after anthesis. NS: no significant difference. 


\subsection{Net Photosynthetic Rate $\left(P_{n}\right)$}

The $P_{n}$ tended to decline with growth stage from 18 DAA to maturity (Figure 3$)$. In all cultivars the leaf $P_{n}$ decreased from the upper leaf (the 9th) to the lower leaf (6th) at the same stage. The $P_{n}$ was higher in the two high-yielding cultivars (XiQiao2 and QianKu3) than in the two low-yielding cultivars (LiuKu3 and JiuJiang) from 27 DAA onwards. Thus, compared with the low-yielding cultivars, the high-yielding cultivars maintained higher $P_{n}$ as the leaves matured.

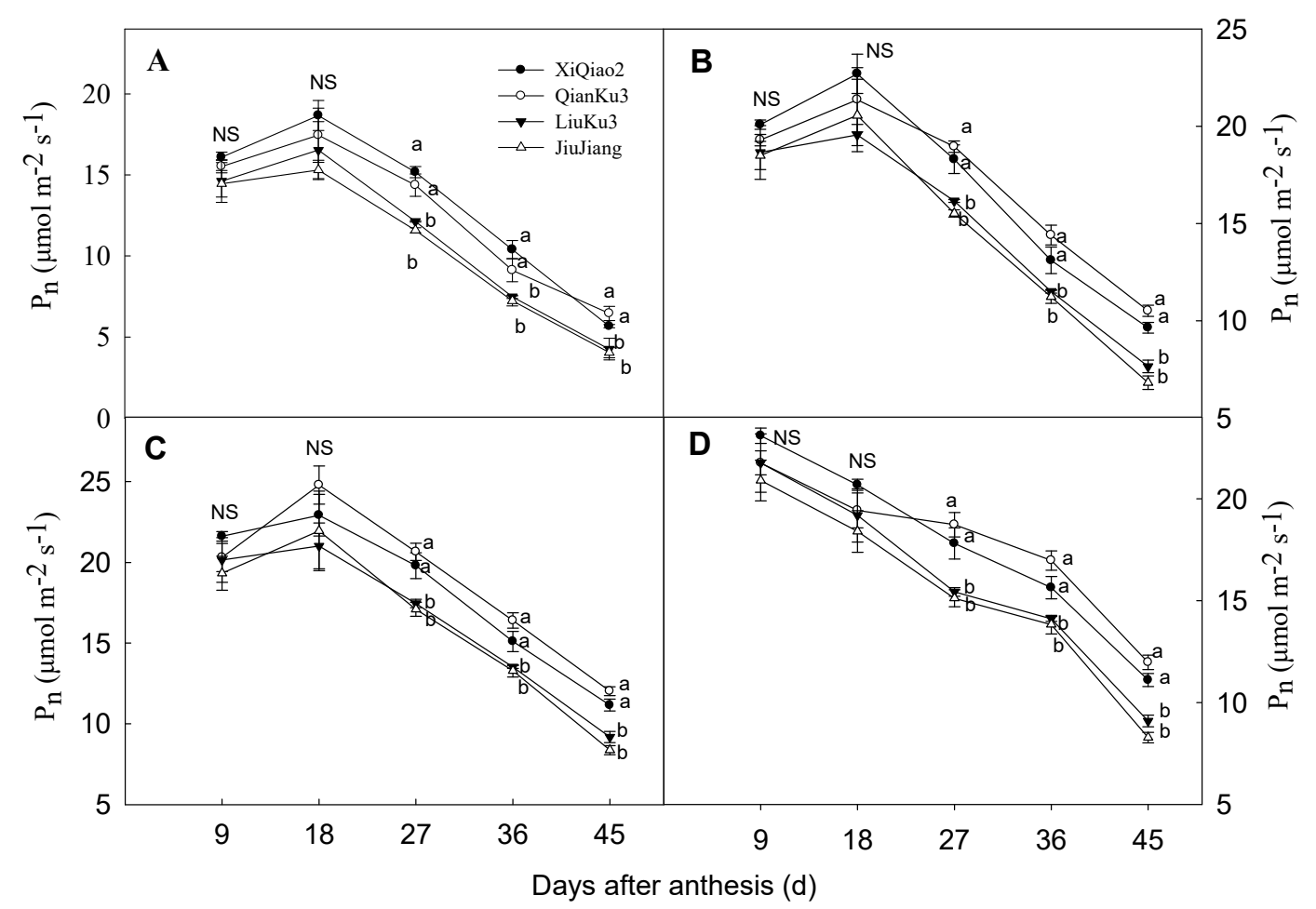

Figure 3. Net photosynthetic rates $\left(P_{n}\right)$ in the leaves of four Tartary buckwheat cultivars at different flowering nodes. Panels (A-D) show results for the leaves of the 6th, 7th, 8 th, and 9 th flowering nodes, respectively. Data are means \pm SD of two years (2016 and 2017). Letters a and b denote significant differences between cultivars $(p<0.05)$ in $\mathrm{P}_{\mathrm{n}}$ at the same day after anthesis. NS: no significant difference.

\subsection{Stomatal Conductance $\left(G_{s}\right)$}

The $G_{S}$ of all four cultivars decreased continuously at each flowering node from 18 DAA to maturity (Figure 4). Comparing the different flowering nodes, the 9 th leaf had the highest $\mathrm{G}_{\mathrm{s}}$, followed by the 8 th and 7 th leaves, and the 6th leaf the lowest at the same stage. The leaf $\mathrm{G}_{\mathrm{s}}$ of all the cultivars tended to decrease over time, but the cultivars differed significantly. From 27 DAA onwards, the leaf $\mathrm{G}_{\mathrm{s}}$ at all flowering nodes was higher in the high-yielding cultivars (XiQiao2 and QianKu3) than in the low-yielding cultivars (LiuKu3 and JiuJiang).

\subsection{Intercellular $\mathrm{CO}_{2}$ Concentration $\left(C_{i}\right)$}

As shown in Figure 5, the $C_{i}$ of the four different cultivars showed the same trend of decrease-increase-decrease with age, peaking at 36 DAA. The two low-yielding cultivars (LiuKu3 and JiuJiang) had significantly higher $C_{i}$ than the two high-yielding cultivars (XiQiao2 and QianKu3) from 27 DAA onwards, and all four functional leaves showed the same trend. 


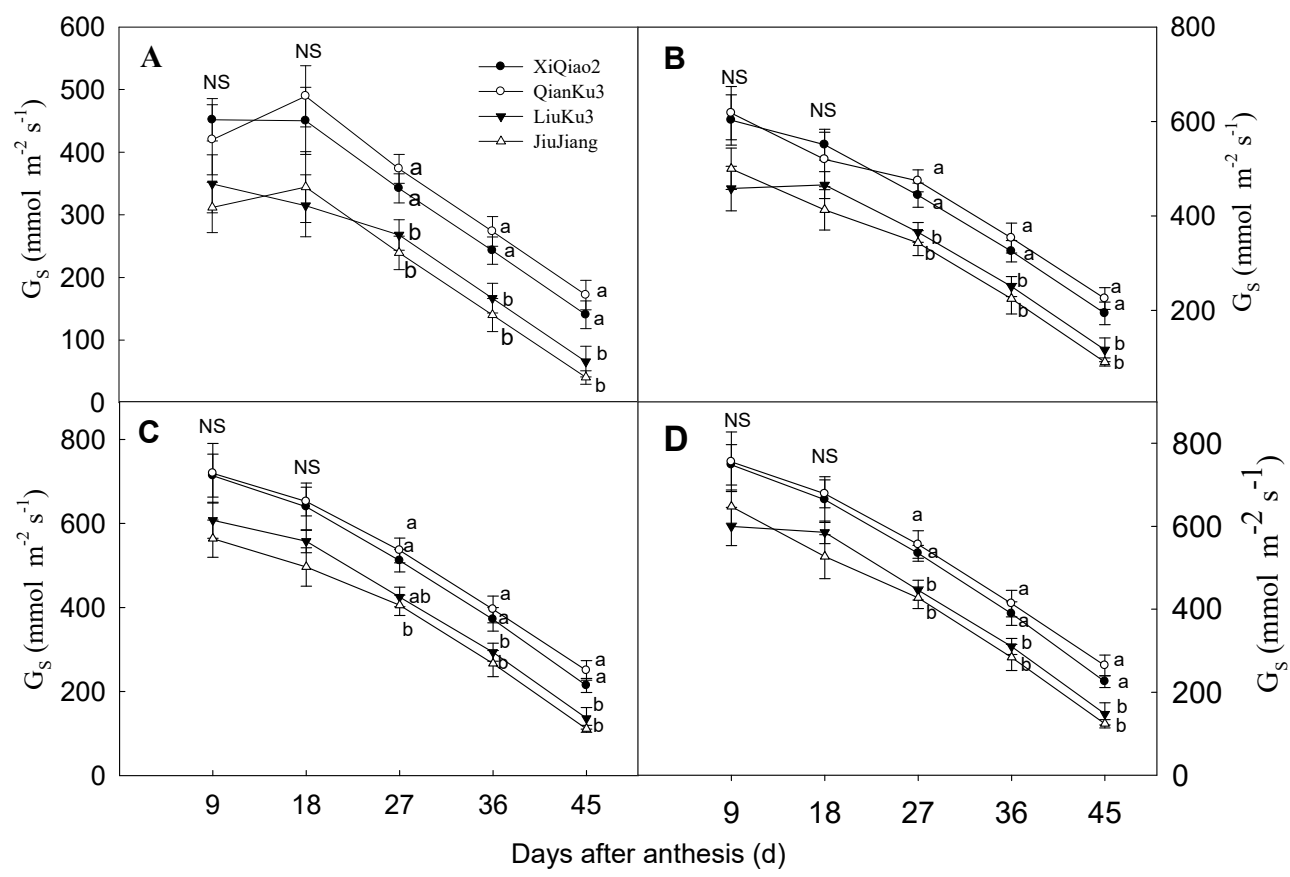

Figure 4. Stomatal conductance $\left(\mathrm{G}_{S}\right)$ in the leaves of four Tartary buckwheat cultivars at different flowering nodes. Panels (A-D) show results for the leaves of the 6th, 7th, 8th, and 9th flowering nodes, respectively. Data are means \pm SD of two years (2016 and 2017). Letters a and b denote significant differences between cultivars $(p<0.05)$ in $\mathrm{G}_{\mathrm{S}}$ at the same day after anthesis. NS: no significant difference.

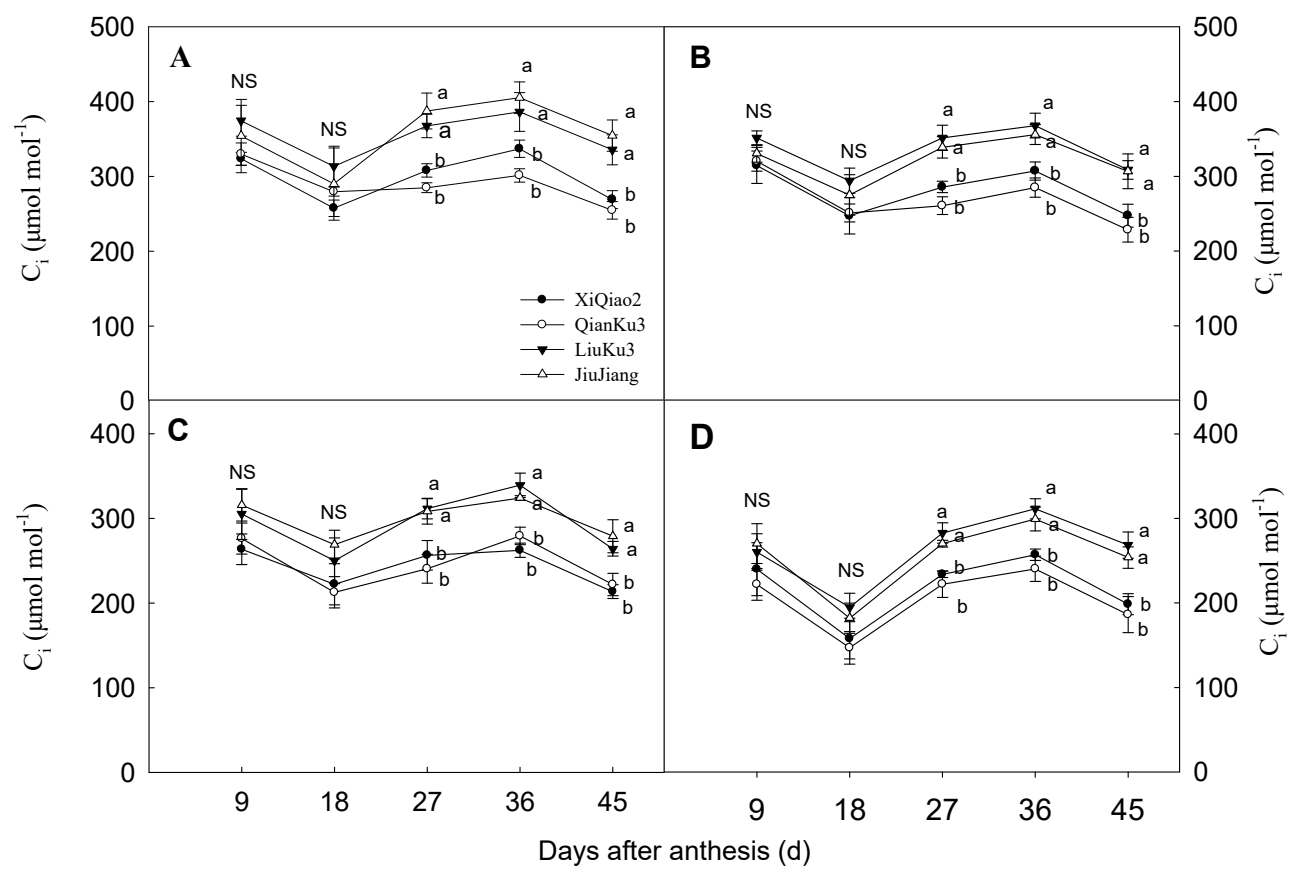

Figure 5. Intercellular $\mathrm{CO}_{2}$ concentration $\left(\mathrm{C}_{\mathrm{i}}\right)$ in the leaves of four Tartary buckwheat cultivars at different flowering nodes. Panels (A-D) show results for the leaves of the 6th, 7th, 8th, and 9th flowering nodes, respectively. Data are the means \pm SD of two years (2016 and 2017). Letters a and b denote significant differences between cultivars $(p<0.05)$ in $\mathrm{G}_{\mathrm{S}}$ at the same day after anthesis. NS: no significant difference.

\subsection{Leaf Transpiration Rate (Tr)}

The $T_{r}$ of all cultivars showed the same trend with an increase at first and then a progressive decrease from flowering to maturity (Figure 6). Comparing the different flowering nodes at the same 
stage, the highest leaf $T_{r}$ was observed in the 9th flowering node and the lowest in the 6th, with the 7th and 8th leaves intermediate. The $T_{r}$ was significantly higher in XiQiao2 and QianKu3 than in the two low-yielding cultivars (LiuKu3 and JiuJiang) at all flowering nodes from 18 DAA to maturity.

\subsection{Total Plant Dry Matter and Harvest Index (HI)}

ANOVA showed that the effect of cultivar was significant on total plant dry matter at the maturity stage (MS), biomass accumulation between 9 DAA and MS, the proportion of dry matter that accumulated from 9 DAA to MS, and HI (Table 2). The high-yielding cultivars (XiQiao2 and QianKu3) had significantly higher dry matter at MS than the cultivars LiuKu3 and JiuJiang. On average, the total dry matter at maturity was $17.1 \%$ higher in XiQiao2 and QianKu3 than in LiuKu3 and JiuJiang. Cultivars significantly affected HI $(p<0.01)$, but the year did not. The HI of XiQiao2 and QianKu3 was on average $17.0 \%$ higher in 2016 and 15.8\% higher in 2017 than that of LiuKu3 and JiuJiang.

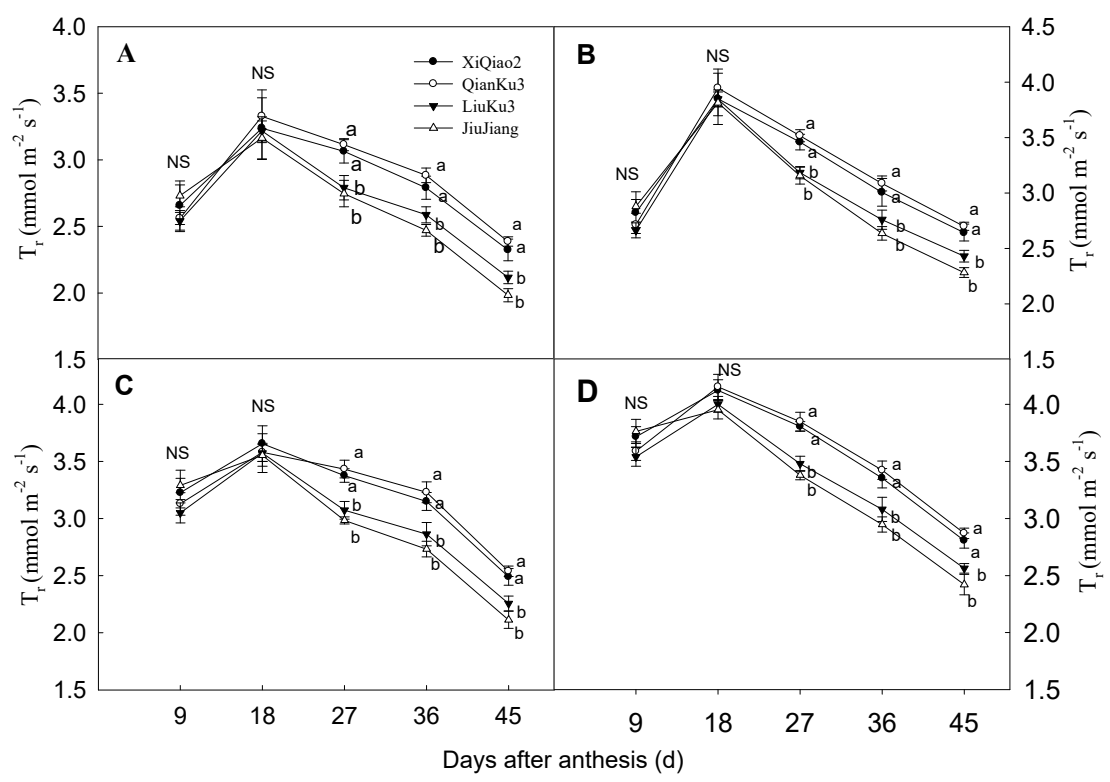

Figure 6. Trend of transpiration rates $\left(T_{r}\right)$ in the leaves of four Tartary buckwheat cultivars at different flowering nodes. Panels (A-D) represent the leaves of 6th, 7th, 8th, and 9th flowering nodes, respectively. Data are the means \pm SD in two years (2016 and 2017). a and b indicate significant difference (at $p<0.05)$ in $\mathrm{T}_{\mathrm{r}}$ at the same day after anthesis among four cultivars. NS represent no significant difference in $\mathrm{T}_{\mathrm{r}}$ at the same day after anthesis among four cultivars.

Table 2. Total plant dry matter $\left(\mathrm{kg} \mathrm{ha}^{-1}\right)$ at $9 \mathrm{~d}$ after anthesis (9 DAA) and maturity stage (MS), biomass accumulation from 9 DAA to MS, proportion of total dry matter accumulated from 9 DAA to MS, and HI in four Tartary buckwheat cultivars in 2016 and 2017.

\begin{tabular}{ccccccc}
\hline Years & Cultivar & 9DAA & From 9 DAA to MS & Proportion & MS & HI \\
\hline \multirow{2}{*}{2016} & XiQiao2 & $2171.5 \mathrm{a}$ & $5726.5 \mathrm{a}$ & $0.725 \mathrm{a}$ & $7898.0 \mathrm{a}$ & $0.313 \mathrm{a}$ \\
& QianKu3 & $2185.1 \mathrm{a}$ & $5740.8 \mathrm{a}$ & $0.724 \mathrm{a}$ & $7925.9 \mathrm{a}$ & $0.307 \mathrm{a}$ \\
& LiuKu3 & $2072.5 \mathrm{a}$ & $4638.2 \mathrm{~b}$ & $0.691 \mathrm{~b}$ & $6710.7 \mathrm{~b}$ & $0.270 \mathrm{~b}$ \\
\multirow{2}{*}{2017} & JiuJiang & $2149.9 \mathrm{a}$ & $4472.1 \mathrm{~b}$ & $0.675 \mathrm{~b}$ & $6622.0 \mathrm{~b}$ & $0.260 \mathrm{~b}$ \\
& XiQiao2 & $2005.8 \mathrm{a}$ & $5574.5 \mathrm{a}$ & $0.736 \mathrm{a}$ & $7580.3 \mathrm{a}$ & $0.306 \mathrm{a}$ \\
& QianKu3 & $2179.1 \mathrm{a}$ & $5738.1 \mathrm{a}$ & $0.725 \mathrm{ab}$ & $7917.2 \mathrm{a}$ & $0.318 \mathrm{a}$ \\
& LiuKu3 & $2006.8 \mathrm{a}$ & $4763.5 \mathrm{~b}$ & $0.704 \mathrm{~b}$ & $6770.3 \mathrm{~b}$ & $0.276 \mathrm{~b}$ \\
& JiuJiang & $2178.5 \mathrm{a}$ & $4473.0 \mathrm{c}$ & $0.672 \mathrm{c}$ & $6651.5 \mathrm{~b}$ & $0.263 \mathrm{~b}$ \\
\hline
\end{tabular}


Table 2. Cont.

\begin{tabular}{ccccccc}
\hline Years & Cultivar & 9DAA & From 9 DAA to MS & Proportion & MS & HI \\
\hline \multirow{2}{*}{ Mean } & 2016 & $2144.8 \mathrm{a}$ & $5144.4 \mathrm{a}$ & $0.704 \mathrm{a}$ & $7289.2 \mathrm{a}$ & $0.287 \mathrm{a}$ \\
& 2017 & $2092.6 \mathrm{a}$ & $5137.3 \mathrm{a}$ & $0.709 \mathrm{a}$ & $7229.8 \mathrm{a}$ & $0.291 \mathrm{a}$ \\
\hline \multirow{2}{*}{ Mean } & XiQiao2 & $2088.7 \mathrm{a}$ & $5650.5 \mathrm{a}$ & $0.730 \mathrm{a}$ & $7739.2 \mathrm{a}$ & $0.309 \mathrm{a}$ \\
& QianKu3 & $2182.1 \mathrm{a}$ & $5739.4 \mathrm{a}$ & $0.725 \mathrm{a}$ & $7921.6 \mathrm{a}$ & $0.312 \mathrm{a}$ \\
& LiuKu3 & $2039.6 \mathrm{a}$ & $4700.9 \mathrm{~b}$ & $0.697 \mathrm{~b}$ & $6740.5 \mathrm{~b}$ & $0.273 \mathrm{~b}$ \\
& JiuJiang & $2164.2 \mathrm{a}$ & $4472.5 \mathrm{c}$ & $0.674 \mathrm{c}$ & $6636.8 \mathrm{~b}$ & $0.262 \mathrm{~b}$ \\
\hline \multirow{2}{*}{ ANOVA } & & & & & \\
\multirow{2}{*}{ F-Value } & Year $(Y)$ & $1.51^{\mathrm{NS}}$ & $0.016^{\mathrm{NS}}$ & $1.79 \mathrm{NS}$ & $0.46^{\mathrm{NS}}$ & $0.90^{\mathrm{NS}}$ \\
& Cultivar $(C)$ & $2.44^{\mathrm{NS}}$ & $130.50^{* *}$ & $47.10^{* *}$ & $58.10^{* *}$ & $44.10^{* *}$ \\
& $Y \times C$ & $1.23^{\mathrm{NS}}$ & $1.53^{\mathrm{NS}}$ & $0.91^{\mathrm{NS}}$ & $2.11^{\mathrm{NS}}$ & $0.88^{\mathrm{NS}}$ \\
\hline
\end{tabular}

9 DAA: $9 \mathrm{~d}$ after anthesis. MS: maturity stage. HI: Harvest Index. Within each column, letters $\mathrm{a}, \mathrm{b}$ and $\mathrm{c}$ denote significant differences between cultivars in a given year $(p<0.05)$. For ANOVA, $Y \times C$ represents the interaction between year and cultivar. ${ }^{\mathrm{NS}}$, not significant. ${ }^{* *}$, significant $(p<0.01)$.

\subsection{Grain Yield and Yield Components}

In both growing seasons, Cultivar significantly affected the number of grains per plant and yield $(p<0.01$; Table 3). XiQiao2 and QianKu3 had the highest yields, with averages over the two experimental years of $2394.25 \mathrm{~kg} \mathrm{ha}^{-1}$ and $2473.7 \mathrm{~kg} \mathrm{ha}^{-1}$, respectively, while LiuKu3 and JiuJiang had the lowest yields. Relative to LiuKu3 and JiuJiang, XiQiao2 and QianKu3 achieved 34.2\% higher grain yields in 2016 and $23.9 \%$ higher grain yields in 2017. The yield components also differed among cultivars. The effect of cultivar was significant for number of grains per plant $(p<0.01)$, but not for effective plants per $\mathrm{m}^{2}$ or 1000-grain weight. The number of grains per plant was significantly higher for XiQiao2 and QianKu3 than for LiuKu3 and JiuJiang. In addition, QianKu3 showed a higher 1000-grain weight than LiuKu3 and JiuJiang, by 7.66\% in 2016 and 7.01\% in 2017.

Table 3. Yield and its components for four Tartary buckwheat cultivars in 2016 and 2017.

\begin{tabular}{|c|c|c|c|c|c|}
\hline Years & Cultivar & $\begin{array}{c}\text { Effective } \\
\text { Plants per } \mathbf{m}^{2}\end{array}$ & $\begin{array}{l}\text { Grains per } \\
\text { Plant }\end{array}$ & $\begin{array}{l}\text { 1000-Grain } \\
\text { Weight (g) }\end{array}$ & $\begin{array}{c}\text { Yield } \\
\left(\mathrm{kg} \mathrm{ha}^{-1}\right)\end{array}$ \\
\hline \multirow[t]{4}{*}{2016} & XiQiao2 & $116.7 \mathrm{a}$ & $133.8 \mathrm{~b}$ & $20.97 \mathrm{ab}$ & $2470.1 \mathrm{a}$ \\
\hline & QianKu3 & $116.5 a$ & $144.3 \mathrm{a}$ & $21.50 \mathrm{a}$ & $2429.2 a$ \\
\hline & LiuKu3 & 117.3a & $105.0 \mathrm{c}$ & $19.97 \mathrm{bc}$ & $1809.5 b$ \\
\hline & JiuJiang & $116.0 \mathrm{a}$ & $110.4 \mathrm{c}$ & $19.33 c$ & $1723.2 b$ \\
\hline \multirow[t]{4}{*}{2017} & XiQiao2 & $117.6 \mathrm{a}$ & $134.8 \mathrm{a}$ & $19.83 \mathrm{ab}$ & $2318.4 a$ \\
\hline & QianKu3 & $113.3 a$ & $140.7 \mathrm{a}$ & $20.90 a$ & $2518.1 \mathrm{a}$ \\
\hline & LiuKu3 & $118.0 \mathrm{a}$ & $105.4 b$ & $19.23 b$ & $1871.5 b$ \\
\hline & JiuJiang & $116.1 \mathrm{a}$ & $111.0 \mathrm{~b}$ & $19.53 b$ & $1752.3 b$ \\
\hline \multirow{2}{*}{ Mean } & 2016 & $116.7 a$ & $123.4 \mathrm{a}$ & $20.4 a$ & $2108.0 \mathrm{a}$ \\
\hline & 2017 & $116.3 a$ & $123.0 \mathrm{a}$ & $19.9 a$ & $2115.1 \mathrm{a}$ \\
\hline \multirow{4}{*}{ Mean } & XiQiao2 & $117.2 \mathrm{a}$ & $134.3 b$ & $20.4 b$ & $2394.3 a$ \\
\hline & QianKu3 & $115.0 \mathrm{a}$ & $142.5 \mathrm{a}$ & $21.1 \mathrm{a}$ & $2473.7 \mathrm{a}$ \\
\hline & LiuKu3 & $117.7 \mathrm{a}$ & $105.2 \mathrm{~d}$ & $19.6 c$ & $1840.5 b$ \\
\hline & JiuJiang & $116.0 \mathrm{a}$ & $110.7 \mathrm{c}$ & $19.4 \mathrm{c}$ & $1737.8 b$ \\
\hline \multicolumn{6}{|l|}{ ANOVA } \\
\hline \multirow{3}{*}{ F-Value } & Year $(Y)$ & $0.18^{\mathrm{NS}}$ & $0.14^{\mathrm{NS}}$ & 4.11 NS & $0.017^{\mathrm{NS}}$ \\
\hline & Cultivar $(C)$ & $1.45^{\mathrm{NS}}$ & $291.8^{* *}$ & 8.44 NS & $47.9 * *$ \\
\hline & $Y \times C$ & $0.98^{\mathrm{NS}}$ & $0.65^{\mathrm{NS}}$ & $2.19 \mathrm{NS}$ & $1.81^{\mathrm{NS}}$ \\
\hline
\end{tabular}

Within each column, letters $\mathrm{a}, \mathrm{b}$ and $\mathrm{c}$ denote significant differences between cultivars in a given year $(p<0.05)$. For ANOVA, $Y \times C$ represents the interaction between year and cultivar. ${ }^{\mathrm{NS}}$, not significant. ${ }^{* *}$ significant $(p<0.01)$. 


\subsection{Correlation between Yield and Photosynthetic Parameters}

As shown in Table 4, the yield of Tartary buckwheat was closely correlated with the photosynthetic parameters of the functional leaves. The $P_{n}, G_{S}, T_{r}, C h l$, and SP were significantly and positively correlated with yield, and correlation analysis also demonstrated that all functional leaves (6th, 7th, 8 th and 9 th) showed the same trend. The $C_{i}$ was significantly and negatively correlated with yield, for all functional leaves.

Table 4. Correlation coefficients between yield and photosynthetic parameters of different functional leaves in Tartary buckwheat.

\begin{tabular}{|c|c|c|c|c|}
\hline Item & The 6th Leaf & The 7th Leaf & The 8th Leaf & The 9th Leaf \\
\hline$P_{n}$ & $0.890^{* *}$ & $0.965^{* *}$ & $0.961^{* *}$ & $0.964^{* *}$ \\
\hline $\mathrm{G}_{\mathrm{s}}$ & $0.939 * *$ & $0.942^{* *}$ & $0.942 * *$ & $0.933^{* *}$ \\
\hline $\mathrm{C}_{\mathrm{i}}$ & $-0.949 * *$ & $-0.933^{* *}$ & $-0.901^{* *}$ & $-0.963^{* *}$ \\
\hline $\mathrm{T}_{\mathrm{r}}$ & $0.954^{* *}$ & $0.953 * *$ & $0.946^{* *}$ & $0.952 * *$ \\
\hline Chl & $0.972 * *$ & $0.970 * *$ & 0.970 ** & 0.923 ** \\
\hline SP & $0.974 * *$ & $0.974^{* *}$ & $0.899^{* *}$ & $0.883^{* *}$ \\
\hline
\end{tabular}

\section{Discussion}

Leaf Chl content plays an essential role in photosynthesis, as it determines the photosynthetic potential and plant productivity, ultimately influencing the crop yield [41]. Chlorophyll content is a physiological trait often suggested as a suitable and sensitive marker when selecting for plant yield [42]. Our data indicated that the Chl contents of four functional leaves (Figure 7) were significantly and positively correlated with the yield of Tartary buckwheat (Table 4). This suggests that an increased Chl content in the functional leaves of this crop might usefully contribute towards achieving higher yields. Analyses of $\mathrm{Chl}$ content during the whole growth period from anthesis to maturity suggested the decline in Chl content was an adverse factor for yield, especially at 18 DAA (Figure 1). We observed that the upper leaves showed a slower rate of descent than the lower leaves, consistent with the results of Kura-Hotta et al. (1987) in rice [43]. From 18 DAA to MS, leaves started to fade, especially the lower leaves. Thus, senescence tended to begin earlier in lower leaves, so that they would no longer be able to provide photosynthate. Prawira-Atmaja et al. [44] also reported the Chl content of crops peaks at earlier growth stages, and then declines through later growth stages: the leaves tend to senescence and photosynthetic capacity decreases [45]. In the current study, the Chl content was higher in the high-yielding cultivars (XiQiao2 and QianKu3) than in LiuKu3 and JiuJiang in later growth stages. The higher photosynthetic potential of XiQiao2 and QianKu3 at these growth stages laid the foundation for higher yield.

In this work, all cultivars showed higher SP content in upper leaves compared with lower leaves (Figure 2), despite all the leaves showing a decrease in SP from flowering to maturity. Cao et al. [46] suggested that SP is a key index of physiological and biochemical activity in plants. Proteins play a protective role in cell function and biological membrane integrity, both of which decline during senescence. In this sense, lower leaves age faster than upper leaves, but the most effective way to improve plant yield would be to adopt measures that would delay the senescence of all leaves. Biswal and Pandey [47] reported that delaying leaf senescence would improve the photosynthetic capacity and increase crop yield [48]. In the present study, SP differed significantly among the four Tartary buckwheat cultivars. The SP content of XiQiao2 and QianKu3 was higher than that of LiuKu3 and Jiujiang from $27 \mathrm{~d}$ after flowering (Figure 2). These results are consistent with the notion that the leaves of high-yielding cultivars maintain higher physiological activity during leaf aging than low-yielding cultivars. Our results also showed that SP was significantly and positively correlated 
with yield (Table 4), suggesting that SP could be used as an indicator for the yield potential of Tartary buckwheat cultivars.

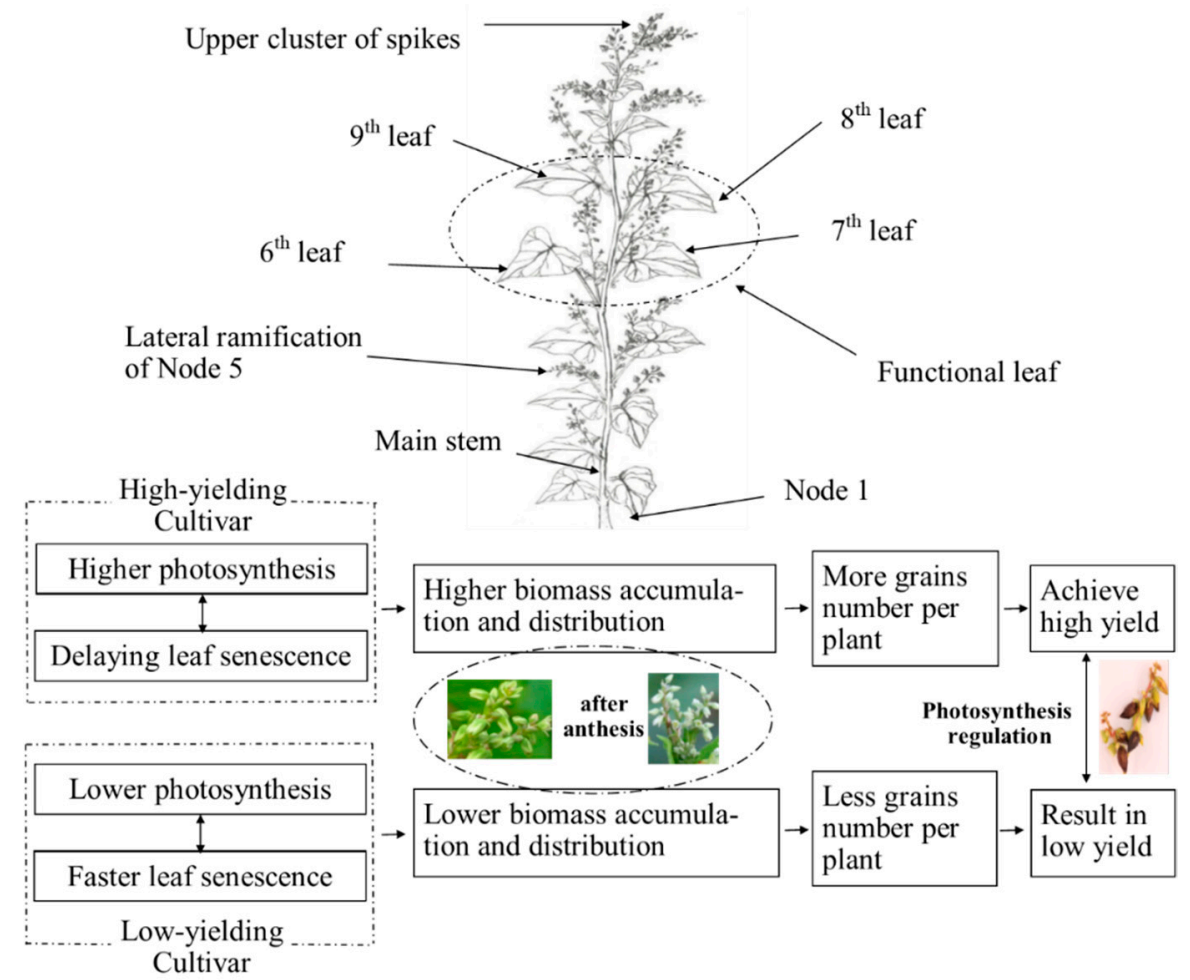

Figure 7. Schematic of plant structure and some factors underlying the performance of high- and low-yielding cultivars of Tartary buckwheat.

Increased photosynthetic capacity is one of the most important factors for grain yield improvement [11], along with increasing the partitioning of biomass to the flower and grains [49]. Different genotypes differ in their photosynthetic capacity, resulting in differences in dry matter accumulation and yield [50]. In the present study there were differences in dynamic changes in $P_{n}, T_{r}$, $\mathrm{C}_{\mathrm{i}}$, and $\mathrm{G}_{\mathrm{s}}$ among the four Tartary buckwheat cultivars. The $\mathrm{P}_{\mathrm{n}}, \mathrm{T}_{\mathrm{r}}$, and $\mathrm{G}_{\mathrm{s}}$ of XiQiao2 and QianKu3 were higher than those of LiuKu3 and JiuJiang from 18 DAA to maturity (Figure 3), but $C_{i}$ showed the opposite trend. Ėatský and Šesták [51] reported that photosynthetic parameters are often affected by environmental factors such as temperature and water supply, as well as leaf age, leaf position and developmental stage. Breznik et al. [52] found that the UV-B radiation could reduce the $\mathrm{Chl} a$ content during the time of intensive growth and affect the photosynthetic capacity of Tartary buckwheat. Interestingly, the addition of selenium was shown to significantly increase the amount of $\mathrm{Chl} a, \mathrm{Chl} b$, and carotenoids and slightly increased the photochemical efficiency of photosystem II (PSII) [53]. Photosynthesis is closely related to crop growth and yield, and higher leaf $\mathrm{P}_{\mathrm{n}}$ is one of the most important factors for high crop yield $[54,55]$. Especially at the mature stage, the low-yielding cultivars LiuKu3 and JiuJiang showed low Chl and SP content (Figures 1 and 2), as well as low photosynthetic capacity (Figure 3). In contrast, the high-yielding cultivars XiQiao2 and QianKu3 showed better performance of photosynthesis and slower leaf aging. The photosynthetic characteristics $\left(P_{n}, G_{s}\right.$ and $\mathrm{T}_{\mathrm{r}}$ ) showed the same tendency (Figures 4 and 6). The high-yielding cultivars XiQiao2 and QianKu3 maintained a lower $\mathrm{C}_{\mathrm{i}}$, presumably because more $\mathrm{CO}_{2}$ was consumed to support higher $\mathrm{P}_{\mathrm{n}}$ (Figure 5). Therefore, high-yielding cultivars had greater capacities to supply their flowers and grains with more carbohydrates during grain growth, whereas the low-yielding cultivars had lower capacities for carbohydrate supply. Thus, the high-yielding cultivars XiQiao2 and QianKu3 accumulated more dry matter and, therefore, achieved higher yields. 
Previous studies have reported that dry matter accumulation is laid on the foundations of traits that are components of yield, especially biomass transfer to the flowers and seeds after anthesis [56-58]. In the present study, the number of grains per plant, yield, and HI were higher in the high-yielding cultivars (XiQiao2 and QianKu3) than in the low-yielding cultivars (LiuKu3 and JiuJiang) (Tables 2 and 3). In addition, we found that the amount of biomass that accumulated from 9 DAA to MS in XiQiao2 and QianKu3 were significantly higher than in LiuKu3 and JiuJiang, being $23.5 \%$ to 28.4\% higher in 2016 and $17.0 \%$ to $28.3 \%$ higher in 2017 (Table 2). Thus, compared with the low-yielding cultivars, the high-yielding cultivars produced more dry matter (and consequently, greater yields) because of their higher rates of photosynthesis and slower leaf senescence (Figures 2 and 3). Similarly, Allison [59] found that dry matter accumulation in maize grains mainly depended on photosynthate production by leaves after anthesis and the subsequent allocation of biomass to the kernels. Therefore, we have reasons to conclude that increasing photosynthesis and delaying the aging of functional leaves would be an effective strategy to improve the yield and yield components in Tartary buckwheat production.

This study also assessed the potential yield advantages if the photosynthetic parameters were altered. Our study showed that the photosynthetic parameters were significantly correlated with yield (Table 4). The Chl and SP contents of Tartary buckwheat peaked at early growth stages when the photosynthetic capacity was the highest. Therefore, the Chl and SP contents reflect the yield potential. These results are supported by several other studies [42,60,61]. Sage and Kubien [62] suggested that photosynthetic parameters are useful as an indirect reference indices for yield because they rapidly respond to changes in environmental conditions. Furthermore, increased photosynthetic capacity is one of the most important methods for potential improvement in grain yield [63,64]. We found that the photosynthetic parameters differed significantly among cultivars, and the differences in those parameters significantly affected yield and its components at physiological maturity. We inferred that the higher grain yield in XiQiao2 and QianKu3 (Table 3) was mainly attributable to higher values of photosynthetic parameters in functional leaves and greater biomass accumulation after anthesis. The higher productivity of dry matter after anthesis laid the foundation for high yield, and improved the HI (Table 2). In turn, these factors led to greater allocation of photosynthate to the flowers and grains in high-yielding cultivars, ultimately resulting in higher yield (Figure 7). Hence, an appropriate method should be used to delay functional leaf aging after anthesis, prolong the functional period of leaves and increase the photosynthetic productivity of Tartary buckwheat. Furthermore, for Tartary buckwheat, the yield advantage of high-yielding cultivars was closely correlated with photosynthetic parameters after anthesis. Therefore, photosynthetic parameters might be valuable as an effective physiological index for evaluating the yield potential of different cultivars. The distribution of dry matter among different organs in Tartary buckwheat and the contribution of photosynthate to yield formation still requires further study.

\section{Conclusions}

Photosynthesis is the main factor that determining the availability of photosynthate and yield potential, and has potential for genetic improvement in Tartary buckwheat. Different cultivars had significantly different photosynthetic capacities, total dry matter accumulation, and yields. High-yielding cultivars showed slower decreases in Chl and SP and maintained leaf function for longer during plant growth, resulting in in higher net photosynthetic rates and dry matter accumulation, and greater distribution of photosynthate to the grains at late growth stages. During the late growth period, the photosynthetic parameters of leaves were significantly and positively correlated with yield (R > $\left.0.88^{* *}\right)$, indicating that they could be useful indices for evaluating yield potential. Hence, to achieve high yielding cultivars in Tartary buckwheat cultivars, breeders should select for high Chl and SP content, slow aging and high photosynthetic parameters in the functional leaves at the flowering nodes. Appropriate cultivation methods may help to optimize these traits and achieve higher yields in field production. 
Author Contributions: D.X. and Y.W. analyzed the results and wrote the manuscript; D.X., C.M., Y.S. (Yue Song), and Q.W. conducted the experiment and collected samples; X.W., Y.X., Y.S. (Yanxia Sun), and G.Z. reviewed and edited the manuscript; all authors read and approved the final manuscript.

Funding: This work was funded by National Natural Science Foundation of China (31771716) and Supported by the earmarked fund for China Agriculture Research System (CARS-08-02A).

Acknowledgments: We thank Huw Tyson, and Jennifer Smith, from Liwen Bianji, Edanz Editing China (www. liwenbianji.cn/ac), for editing the English text of a draft of this manuscript.

Conflicts of Interest: The authors declare no conflict of interest.

\section{References}

1. Peng, L.X.; Huang, Y.F.; Liu, Y.; Zhang, Z.F.; Lu, L.Y.; Zhao, G. Evaluation of essential and toxic element concentrations in buckwheat by experimental and chemometric approaches. J. Integr. Agric. 2014, 13, 1691-1698. [CrossRef]

2. Xiang, D.B.; Zhao, G.; Wan, Y.; Tan, M.L.; Song, C.; Song, Y. Effect of planting density on lodging-related morphology, lodging rate, and yield of tartary buckwheat (Fagopyrum tataricum). Plant Prod. Sci. 2016, 19, 479-488. [CrossRef]

3. Fabjan, N.; Rode, J.; Košir, I.J.; Wang, Z.; Zhang, Z.; Kreft, I. Tartary buckwheat (Fagopyrum tataricum Gaertn.) as a source of dietary rutin and quercitrin. J. Agric. Food Chem. 2003, 51, 6452-6455. [CrossRef]

4. Zhao, G.; Zhao, J.L.; Peng, L.X.; Zou, L.; Wang, J.B.; Zhong, L.Y.; Xiang, D.B. Effects of yeast polysaccharide on growth and flavonoid accumulation in Fagopyrum tataricum sprout cultures. Molecules 2012, 17, 11335-11345. [CrossRef]

5. Qin, P.; Wu, L.; Yao, Y.; Ren, G. Changes in phytochemical compositions, antioxidant and $\alpha$-glucosidase inhibitory activities during the processing of tartary buckwheat tea. Food Res. Int. 2013, 50, 562-567. [CrossRef]

6. Wang, L.; Yang, X.; Qin, P.; Shan, F.; Ren, G. Flavonoid composition, antibacterial and antioxidant properties of tartary buckwheat bran extract. Ind. Crop Prod. 2013, 49, 312-317. [CrossRef]

7. Bonafaccia, G.; Marocchini, M.; Kreft, I. Composition and technological properties of the flour and bran from common and Tartary buckwheat. Food Chem. 2003, 80, 9-15. [CrossRef]

8. Kreft, M. Buckwheat phenolic metabolites in health and disease. Nutr. Res. Rev. 2016, 29, 30-39. [CrossRef]

9. Li, S.Q.; Zhang, Q.H. Advances in the development of functional foods from buckwheat. Crit. Rev. Food Sci. 2001, 41, 451-464. [CrossRef]

10. FAOSTAT (Statistics Division of Food and Agriculture Organization of the United Nations). Available online: http:/ / faostat3.fao.org/browse/Q/QC/E (accessed on 4 February 2016).

11. Li, C.F.; Tao, Z.Q.; Liu, P.; Zhang, J.W.; Zhuang, K.Z.; Dong, S.T.; Zhao, M. Increased grain yield with improved photosynthetic characters in modern maize parental lines. J. Integr. Agric. 2015, 14, 1735-1744. [CrossRef]

12. Iqbal, M.; Khan, K.; Sher, H.; Rahman, H.; Al-Yemeni, M.N. Genotypic and phenotypic relationship between physiological and grain yield related traits in four maize (Zea mays L.) crosses of subtropical climate. Sci. Res. Essays 2011, 6, 2864-2872.

13. Zlatev, Z.; Lidon, F.C. An overview on drought induced changes in plant growth, water relations and photosynthesis. Emir. J. Food Agric. 2012, 24, 57-72.

14. Jiang, D.; Dai, T.; Jing, Q.; Cao, W.; Zhou, Q.; Zhao, H.; Fan, X. Effects of long-term fertilization on leaf photosynthetic characteristics and grain yield in winter wheat. Photosynthetica 2004, 42, 439-446. [CrossRef]

15. Subrahmanyam, D.; Subash, N.; Haris, A.; Sikka, A.K. Influence of water stress on leaf photosynthetic characteristics in wheat cultivars differing in their susceptibility to drought. Photosynthetica 2006, 44, 125-129. [CrossRef]

16. Khan, H.R.; Paull, J.G.; Siddique, K.H.M.; Stoddard, F.L. Faba bean breeding for drought-affected environments: A physiological and agronomic perspective. Field Crops Res. 2010, 115, 279-286. [CrossRef]

17. Sui, X.L.; Mao, S.L.; Wang, L.H.; Zhang, B.X.; Zhang, Z.X. Effect of Low Light on the Characteristics of Photosynthesis and Chlorophyll a Fluorescence During Leaf Development of Sweet Pepper. J. Integr. Agric. 2012, 11, 1633-1643. [CrossRef] 
18. Afreen, F.; Zobayed, S.M.A.; Kozai, T. Photoautotrophic culture of Coffea arabusta somatic embryos: Photosynthetic ability and growth of different stage embryos. Ann. Bot. 2002, 90, 11-19. [CrossRef] [PubMed]

19. Shimono, H.; Hasegawa, T.; Fujimura, S.; Lwama, K. Responses of leaf photosynthesis and plant water status in rice to low water temperature at different growth stages. Field Crops Res. 2004, 89, 71-83. [CrossRef]

20. Zhao, G.; Shang, F. Tartary Buckwheat of China; Science Press: Beijing, China, 2009; pp. 50-75.

21. Xiang, D.B.; Peng, L.X.; Zhao, J.L.; Zou, L.; Zhao, G.; Song, C. Effect of drought stress on yield, chlorophyll contents and photosynthesis in tartary buckwheat (Fagopyrum tataricum). J. Food Agric. Environ. 2013, 11, 1358-1363.

22. Wu, H.; Xiang, J.; Zhang, Y.P.; Zhang, Y.K.; Peng, S.B.; Chen, H.Z.; Zhu, D.F. Effects of post-anthesis nitrogen uptake and translocation on photosynthetic production and rice yield. Sci. Rep. 2018, 8, 12891. [CrossRef] [PubMed]

23. Ding, L.; Wang, K.J.; Jiang, G.M.; Liu, M.Z.; Niu, S.L.; Gao, L.M. Post-anthesis changes in photosynthetic traits of maize hybrids released in different years. Field Crops Res. 2005, 93, 108-115. [CrossRef]

24. Xu, C.S.; Xia, Z.Q.; Zhou, X.J.; Huang, J.; Huang, Z.Q.; Liu, Y.; Jiang, Y.W.; Casteel, S.; Zhang, C.K. Physiological and transcriptomic responses of reproductive stage soybean to drought stress. Plant Cell Rep. 2018, 37, 1611-1624. [CrossRef] [PubMed]

25. Mitchell, P.L.; Sheehy, J.E. Supercharging rice photosynthesis to increase yield. New Phytol. 2006, 171, 688-693. [CrossRef] [PubMed]

26. Rogers, A.; Allen, D.J.; Davey, P.A.; Morgan, P.B.; Ainsworth, E.A.; Bernacchi, C.J.; Cornic, G.; Dermody, O.; Dohleman, F.G.; Heaton, E.A.; et al. Leaf photosynthesis and carbohydrate dynamics of soybeans grown throughout their life-cycle under Free-Air Carbon dioxide Enrichment. Plant Cell Environ. 2004, 27, 449-458. [CrossRef]

27. Ou, Z.Y.; Peng, C.L.; Lin, G.Z. Photosynthetic Characteristics in flag leaves of super high-yielding hybrid rice Peiai64S/E32 and its parents grown in the field. Acta Agron. Sin. 2005, 2, 209-213.

28. Zhang, L.H.; Zhao, H.X.; Tan, G.B.; Yan, W.P.; Fang, X.Q.; Meng, X.M.; Bian, S.F. Influence of water and fertilizer coupling on photosynthetic characters and yield of soybean. Soybean Sci. 2010, 2, 268-271.

29. Wang, C.; She, H.Z.; Liu, X.B.; Hu, D.; Ruan, R.W.; Shao, M.B.; Zhang, L.Y.; Zhou, L.B.; Zhang, G.B.; Wu, D.Q.; et al. Effects of fertilization on leaf photosynthetic characteristics and grain yield in tartary buckwheat Yunqiao1. Photosynthetica 2017, 55, 77-84. [CrossRef]

30. Fayez, K.A.; Hassanein, A.M. Chlorophyll Synthesis Retardation and Ultrastructural Alterations to Solanum tuberosum Chloroplasts in Solanum nigrum Cells. Photosynthetica 2000, 38, 37-44. [CrossRef]

31. Maydup, M.L.; Antonietta, M.; Guiamet, J.J.; Graciano, C.; López, J.R.; Tambussi, E.A. The contribution of ear photosynthesis to grain filling in bread wheat (Triticum aestivum L.). Field Crops Res. 2010, 119, 48-58. [CrossRef]

32. Liu, Y.; Liang, X.; Zhou, F.; Zhang, Z. Accessing the agronomic and photosynthesis-related traits of high-yielding winter wheat mutants induced by ultra-high pressure. Field Crops Res. 2017, 213, 165-173. [CrossRef]

33. Thakur, A.K.; Mandal, K.G.; Mohanty, R.K.; Ambast, S.K. Rice root growth, photosynthesis, yield and water productivity improvements through modifying cultivation practices and water management. Agric. Water Manag. 2018, 206, 67-77. [CrossRef]

34. Wang, A.H.; Xia, M.Z.; Cai, G.Z.; Dai, H.Y. Buckwheat new variety XiQiao No. 2 with high yield and excellent quality. Seed 2009, 10, 110-112.

35. Wang, X.S.; Yang, C.X. Comparative study of different tartary buckwheat cultivars in hilly region of NingXia Province. Modern Agric. Sci. Technol. 2009, 11, 171-172.

36. Mao, C.; Cheng, G.Y.; Cai, F.; Sun, J.N. Breeding and cultivation technology of new buckwheat variety Qianku No. 3. Seed 2010, 7, 111-113.

37. Wang, H.; Yang, Y.; Yang, M.J.; Shi, J.B.; Guo, Z.X. Screening of tartary buckwheat varieties in the Northern Shanxi area. J. Shanxi Agric. Sci. 2013, 41, 321-323.

38. Wang, Y.; Liang, C.G.; Sun, Y.H.; Yu, W.J.; Liao, K.; Huang, Y.W.; Shi, T.X.; Chen, Q.J.; Meng, Z.Y. The yield and quality of tartary buckwheat varieties and the response to low nitrogen. J. Guizhou Normal Univ. (Nat. Sci.) 2017, 6, 66-72. 
39. Pang, X.Y.; Bao, W.K.; Zhang, Y.M. Evaluation of soil fertility under different Cupressus chengiana forests using multivariate approach. Pedosphere 2006, 16, 602-615. [CrossRef]

40. Xiong, Q.E. Guide for Plant Physiology Experiment; Sichuan Science and Technology Press: Chengdu, China, 2009; pp. 85-86.

41. Ahammed, G.J.; Wen, X.; Airong, L.; Shuangchen, C. COMT1 silencing aggravates heat stress-induced reduction in photosynthesis by decreasing chlorophyll content, photosystem II activity, and electron transport efficiency in tomato. Front. Plant Sci. 2018, 9, 998-1007. [CrossRef]

42. Silva, M.A.; Jifon, J.L.; Da, S.J.A.G.; Sharma, V. Use of physiological parameters as fast tools to screen for drought tolerance in sugarcane. Braz. J. Plant Physiol. 2007, 19, 193-201. [CrossRef]

43. Kura-Hotta, M.; Satoh, K.; Katoh, S. Relationship between photosynthesis and chlorophyll content during leaf senescence of rice seedlings. Plant Cell Physiol. 1987, 28, 1321-1329.

44. Prawira-Atmaja, M.I.; Khomaini, H.S.; Maulana, H.; Harianto, S.; Rohdiana, D. Changes in chlorophyll and polyphenols content in Camellia sinensis var. sinensis at different stage of leaf maturity. IOP Conf. Ser. Earth Environ. Sci. 2018, 131, 012010.

45. Zhang, K.; Zhang, Y.; Chen, G.; Tian, J. Genetic analysis of grain yield and leaf chlorophyll content in common wheat. Cereal Res. Commu. 2009, 37, 499-511. [CrossRef]

46. Cao, X.C.; Chu, Z.; Zhu, L.F.; Zhang, J.H.; Hussain, S.; Wu, L.H.; Jin, Q.Y. Glycine increases cold tolerance in rice via the regulation of $\mathrm{n}$ uptake, physiological characteristics, and photosynthesis. Plant Physiol. Biochem. 2017, 112, 251-260.

47. Biswal, B.; Pandey, J.K. Loss of photosynthesis signals a metabolic reprogramming to sustain sugar homeostasis during senescence of green leaves: Role of cell wall hydrolases. Photosynthetica 2018, 56, 404-410. [CrossRef]

48. Song, Y.; Zhang, Z.; Tan, X.J.; Jiang, Y.F.; Gao, J.G.; Lin, L.; Wang, Z.H.; Ren, J.; Wang, X.L.; Qin, L.Q.; et al. Association of the molecular regulation of ear leaf senescence/stress response and photosynthesis/ metabolism with heterosis at the reproductive stage in maize. Sci. Rep. 2016, 6, 29843. [CrossRef]

49. Chen, X.; Hao, M.D. Low contribution of photosynthesis and water-use efficiency to improvement of grain yield in Chinese wheat. Photosynthetica 2015, 53, 519-526. [CrossRef]

50. Wei, H.H.; Meng, T.Y.; Li, C.; Xu, K.; Huo, Z.Y.; Wei, H.Y.; Guo, B.W.; Zhang, H.C.; Dai, Q.G. Comparisons of grain yield and nutrient accumulation and translocation in high-yielding japonica/indica hybrids, indica hybrids, and japonica conventional varieties. Field Crops Res. 2017, 204, 101-109. [CrossRef]

51. Ėatský, J.; Šesták, Z. Photosynthesis during leaf development. In Handbook of Photosynthesis; Pessarakli, M., Ed.; Marcel Dekker: New York, NY, USA, 1997; pp. 633-660.

52. Breznik, B.; Germ, M.; Gaberščik, A.; Kreft, I. Combined effects of elevated UV-B radiation and the addition of selenium on common (Fagopyrum esculentum Moench) and tartary [Fagopyrum tataricum (L.) Gaertn.] buckwheat. Photosynthetica 2005, 43, 583-589. [CrossRef]

53. Golob, A.; Stibilj, V.; Nečemer, M.; Kump, P.; Kreft, I.; Hočevara, A.; Gaberščik, A.; Germ, M. Calcium oxalate druses affect leaf optical properties in selenium-treated Fagopyrum tataricum. J. Photochem. Photobiol. B 2018, 180, 51-55. [CrossRef]

54. Allakhverdiev, S.I.; Kreslavski, V.D.; Klimov, V.V.; Los, D.A.; Carpentier, R.; Mohanty, P. Heat stress: An overview of molecular responses in photosynthesis. Photosynth. Res. 2008, 98, 541-550. [CrossRef] [PubMed]

55. Lawlor, D.W.; Tezara, W. Causes of decreased photosynthetic rate and metabolic capacity in water-deficient leaf cells: A critical evaluation of mechanisms and integration of processes. Ann. Bot. 2009, 103, 561-579. [CrossRef]

56. Taylor, R.S.; Weaver, D.B.; Wood, C.W.; Van Santen, E. Nitrogen application increases yield and early dry matter accumulation in late-planted soybean. Crop Sci. 2005, 45, 854-858. [CrossRef]

57. Ehdaie, B.; Alloush, G.A.; Waines, J.G. Genotypic variation in linear rate of grain growth and contribution of stem reserves to grain yield in wheat. Field Crops Res. 2008, 106, 34-43. [CrossRef]

58. Tang, Y.; Wu, X.; Li, C.; Yang, W.; Huang, M.; Ma, X.; Li, S. Yield, growth, canopy traits and photosynthesis in high-yielding, synthetic hexaploid-derived wheats cultivars compared with non-synthetic wheats. Crop Pasture Sci. 2017, 68, 115. [CrossRef]

59. Allison, J.C.S. Effect of plant population on the production and distribution of dry matter in maize. Ann. Appl. Biol. 1969, 63, 135-144. [CrossRef] 
60. Mirasson, H.R.; Faraldo, M.L.; Fioretti, M.N.; Miravalles, M.; Brevedan, R.E. Relationship between leaf greenness index and leaf water status in wheat under different tillage systems. Phyton 2010, 79, 183-187.

61. Sun, Y.Y.; Wang, X.L.; Wang, N.; Chen, Y.L.; Zhang, S.Q. Changes in the yield and associated photosynthetic traits of dry-land winter wheat (Triticum aestivum L.) from the 1940s to the 2010s in Shaanxi Province of China. Field Crops Res. 2014, 167, 1-10. [CrossRef]

62. Sage, R.F.; Kubien, D.S. The temperature response of C3 and C4 photosynthesis. Plant Cell Environ. 2007, 30, 1086-1106. [CrossRef] [PubMed]

63. Fischer, R.A.; Aguilar, M.L. Yield potential in a dwarf spring wheat and the effect of carbon dioxide fertilization. Agron. J. 1976, 68, 40-43. [CrossRef]

64. Xue, J.; Gou, L.; Shi, Z.G.; Zhao, Y.S.; Zhang, W.F. Effect of leaf removal on photosynthetically active radiation distribution in maize canopy and stalk strength. J. Integr. Agric. 2017, 161, 85-96. [CrossRef]

(C) 2019 by the authors. Licensee MDPI, Basel, Switzerland. This article is an open access article distributed under the terms and conditions of the Creative Commons Attribution (CC BY) license (http://creativecommons.org/licenses/by/4.0/). 